\title{
Domestic threats and foreign policy agenda: a security perspective on Turkey's Iran policy
}

\section{Cagla Luleci-Sula}

To cite this article: Cagla Luleci-Sula (2018): Domestic threats and foreign policy agenda: a security perspective on Turkey's Iran policy, British Journal of Middle Eastern Studies, DOI: 10.1080/13530194.2018.1549980

To link to this article: https://doi.org/10.1080/13530194.2018.1549980

\section{Published online: 30 Nov 2018.}

Submit your article to this journal $\pi$

Џll Article views: 141

View Crossmark data ¿ 


\title{
Domestic threats and foreign policy agenda: a security perspective on Turkey's Iran policy
}

\author{
Cagla Luleci-Sula (iD)
}

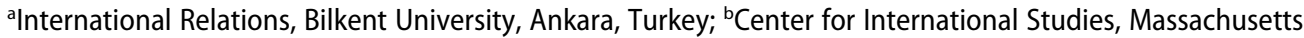
Institute of Technology, MA, USA

\begin{abstract}
Starting from the Islamic Revolution, Iran's regime had increasingly been presented as the external source of Islamic fundamentalist movements in Turkey, leading to the establishment of a securitydriven atmosphere in bilateral relations. However, Turkish-Iranian relations witnessed a positive change in the 2000s. The impact of the security discourse of Turkish elites regarding Iran's Islamic regime declined and a rapprochement process began. This research suggests that such shift in Turkey's foreign policy agenda became possible with the desecuritization of Islamic fundamentalism in Turkey's domestic politics. The article proposes a securitization framework to analyse the link between domestic politics and foreign policy. Accordingly, it asks 'How did the desecuritization of Islamic fundamentalism in Turkey's domestic politics influence its foreign policy towards Iran?' It analyses Turkey's Iran policy comparatively in the 1990s and 2000s by utilizing speeches of Turkey's political elites, public opinion in Turkey, changing the domestic political structure and alterations in foreign policy practices of Turkey towards Iran.
\end{abstract}

Relations between Turkey and Iran witnessed significant changes following Iran's Islamic Revolution. After a decade of limited bilateral relations in the 1980s, and tense relations in the 1990s, one can observe a positive change in both the discourse and the practices of Turkey towards Iran in the 2000s. In the post-Cold War era, Turkey's foreign policy towards Iran was dominated by the country's domestic political concerns. Fluctuations in Turkey's Iran policy were closely related to the perceptions of the country's political elites on Iran's Islamic regime. Based on this observation the article asks: 'How did the desecuritization of Islamic fundamentalism in Turkey's domestic politics influence its foreign policy agenda towards Iran?'. It suggests that throughout the 1980s the securitization of Islamic fundamentalism in domestic politics deteriorated Turkey's relations with 
Iran. ${ }^{1}$ The securitizing discourse of Turkey's elites regarding Islamic fundamentalism was transposed to Iran as a foreign source and reflected in Turkey's foreign policy towards Iran. However, alterations in the security considerations of Turkey, in other words, the desecuritization of Islamic fundamentalism in the domestic politics of the country, paved the way for the improvement in Turkish-Iranian relations in the 2000s. ${ }^{2}$

Academic literature on the determinants of Turkish-Iranian relations is wide and rich, and can be analysed under three categories. First group focuses on geopolitical and structural factors. These factors are chosen either from the global level such as global alliance system of the Cold War, and balancing or bandwagoning behaviours following the increasing manoeuvring capacity in the post-Cold War; or from the regional level such as competition over regional leadership in the Middle East, the Caucasus and Central Asia, regional alliances in the Middle East, and Iran-Iraq War. Many of these studies do acknowledge the significance of domestic factors, but they argue that the main determinant of change in relations is geopolitical developments such as TurkishIranian competition in Iraq, the Arab Spring, the Syrian Crisis, Turkish-Kurdish Regional Government rapprochement. ${ }^{3}$

\footnotetext{
'I translate 'irtica' as 'Islamic fundamentalism' throughout the article. Irtica is originally an Ottoman/Arabic word which is still used in modern Turkish language, and its literal translation in Ottoman/Turkish-English dictionaries is 'reaction (ism)'. It means 'to react to the current situation, to have a desire to turn back, or to take (reforms) back, and to have the "old" (legal and political) system' (Ferit Devellioglu, Osmanlıca Turkce Ansiklopedik Lugat (Ankara, Aydın Kitabevi Yayınları, 2007). In the context of Turkish politics, the 'old' in irtica refers to establishing a state ruled by Islamic regulations (sharia) and practices as in the Ottoman Empire before the establishment of the Turkish Republic. The word started to be widely used during the 31 March Incident in 1908 during the Ottoman Empire times, referring to the movements that were opposed to constitutionalism. However, in the literature on history of Islam irtica is also used as 'going back to the days of ignorance/jahiliyyah' in which Islam was not accepted yet. In this sense, reactionism does not always refer to 'a will for having an Islamic/Sharia regime' but can be quite contrary. Considering this, I think, 'Islamic fundamentalism' is a better translation than reactionism for the subject of this article. Yet it is significant to clarify that the words 'Islamic fundamentalism' throughout the article refer to 'Islamic fundamentalist reactionism' in the context of Turkish politics. Reactionism, used alone, can be translated into Turkish as not 'irtica' but 'gericilik'. (An Ottoman newspaper titled 'Ikdam' was one of the publishings that used the word 'irtica' in a similar way that is used in contemporary Turkish politics. The newspaper is available online in Ottoman language at http://gazeteler.ankara.edu.tr/detail.php?id=56\&sayi_id=1315).

${ }^{2}$ Buzan, Wæever, and de Wilde expand security concept by defining five sectors: military, political, economic, environmental and societal (Barry Buzan, Ole Wæever, and Jaap de Wilde, Security, A New Framework for Analysis (Boulder, Lynne Rienner Publishers, 1998)). Two main types of political threats are identified: internal and external legitimacy issues. If there is a threat to the ideology that is a decisive feature of the state's identity, this is defined as an internal political security issue. If external legitimacy is considered as in danger, the problem is generally related to the external recognition of a state. In Turkish-Iranian case, the problem is rather an internal political security problem since the secular ideology of the Turkish state is perceived as endangered by the danger of Islamic fundamentalism in the 1990s. In other words, since this study deals with Turkish-Iranian relations in terms of Islamic fundamentalism as a threat to Turkey's secular regime, and this threat's links with Iran, it covers political sector which is about relationships of authority, and related to threats to the legitimacy or recognition of political units, or structures, processes, institutions, etc.

${ }^{3}$ Classified respectively as, Nur Bilge Criss, and Serdar Güner, 'Geopolitical Configurations: The Russia-Turkey-Iran Triangle', Security Dialogue 30, no. 3 (1999): 365-376; Robert Olson, 'Relations among Turkey, Iraq, Kurdistan-Iraq, the Wider Middle East, and Iran', Mediterranean Quarterly 17, no. 4 (2006): 13-45; Robert Olson, 'Turkey-Iran Relations, 1997 to 2000, The Kurdish and Islamist Questions', Third World Quarterly 21, no. 5 (2000): 871-90; William Kang, and Jaechun Kim, 'Turco-Iranian Alignment, Balancing or Bandwagoning with the US?' Journal of International and Area Studies 23, no. 1 (2016): 17-32; Shahram Akbarzadeh, and James Barry, 'Iran and Turkey: Not Quite Enemies but Less than Friends', Third World Quarterly 38, no. 4 (2017): 980-95; S. Gulden Ayman, 'Turkey and Iran, Between Friendly Competition and Fierce Rivalry', Arab Studies Quarterly 36, no. 1 (2014): 6-26; E. Fuat Keyman, and Onur Sazak, 'Turkey and Iran: The Two Modes of Engagement in the Middle East', Journal of Balkan and Near Eastern Studies, 17, no. 3 (2015): 321-36; F. Stephen Larrabee and Alireza Nader, 'Turkey and Iran in a Changing Middle East', in Turkish-Iranian Relations in a Changing Middle East (CA, RAND, 2013), 5-14.
} 
The second group argues that Turkey's changing foreign policy towards Iran can best be explained by analysing the changes in Turkey's domestic politics. ${ }^{4} \mathrm{~A}$ majority of these studies present Turkey's new foreign policy vision in the AKP period as a departure point from the 1980s and 1990s. In this sense, strategic depth doctrine of Turkey's foreign policy is presented as the main determinant of its changing foreign policy behaviour towards its neighbours including Iran. ${ }^{5}$ Apart from strategic depth, ruling elite's foreign policy role conceptions, role of ideology, Kurdish collective identity, Turkey's changing domestic and foreign security perceptions are presented as significant determinants of bilateral relations. ${ }^{6}$

A third group of studies take multiple elements into consideration, suggesting that the interplay of domestic factors with the regional and international systems is significant to understand relations between Iran and Turkey. ${ }^{7}$ For instance, Sinkaya argues that rationalization of foreign policy approaches in Turkey and Iran, together with a supportive regional environment paved the way for rapprochement between two states. ${ }^{8}$ Hale examines how the inauguration of Obama as the US's new president, and appointment of Davutoğlu as Turkey's new foreign minister have an impact on the Middle Eastern politics. ${ }^{9}$ The article put emphasis on both global and regional developments, as well as Turkey's zero problem with its neighbours policy. Calabrese analyses turbulent relations between Turkey and Iran which he considers to be crucial for the stability and prosperity of the Middle East. The article analyses many international (unipolarity and globalization), regional (Arab-Israeli conflict, defeat of Iraq and the Gulf War, independence of some Central Asian states), and domestic factors (ideology) as determinants of friendly/ conflictual relations between Turkey and Iran. ${ }^{10}$ In his book on Turkey-Iran relations after the Islamic Revolution, Elik also analyses many factors, including the impact of the Cold War, Central Asia and the Caucasus policies, economic ties, religion and Turkey's PKK question. $^{11}$

\footnotetext{
${ }^{4}$ Bulent Aras and Rabia Karakaya Polat, 'From Conflict to Cooperation, Desecuritization of Turkey's Relations with Syria and Iran', Security Dialogue 39, no. 5 (2008): 495-515.

${ }^{5} \mathrm{~F}$. Stephen Larrabee, 'Turkey Rediscovers the Middle East', Foreign Affairs 86, no. 4 (2007): 103-114; Alexander Murinson, 'The Strategic Depth Doctrine of Turkish Foreign Policy', Middle Eastern Studies 42, no. 6 (2006): 945964; Anoushiravan Ehteshami, and Süleyman Elik, 'Turkey's Growing Relations with Iran and Arab Middle East', Turkish Studies 12, no. 4 (2011): 643-62; Bulent Aras, and Rabia Karakaya Polat, 'Turkey and the Middle East: Frontiers of the New Geographic Imagination', Australian Journal of International Affairs 61, no. 4 (2008): 471-88; Bulent Aras, 'Turkish Foreign Policy towards Iran: Ideology and Foreign Policy in Flux', Journal of Third World Studies 18, no. 1 (2001): 10524.

${ }^{6}$ Özgür Özdamar, B. Toygar Halistoprak, and İ. Erkam Sula, 'From Good Neighbor to Model: Turkey's Changing Roles in the Middle East in the Aftermath of the Arab Spring', Uluslararası Illişkiler 11, no. 42 (2014): 93-113; Bayram Sinkaya, 'Turkey-Iran Relations in the 1990s and the Role of Ideology', Perceptions Journal of International Affairs 10, no. 1 (2005): 1-16; Julide Karakoc, 'The Impact of the Kurdish Identity on Turkey's Foreign Policy from the 1980s to 2008', Middle Eastern Studies 46, no.6 (2010): 919-42; Rahmat Hajimineh, 'Analyzing the Turkish-Iranian Relations from the Copenhagen School's Point of View', Discourse, An Iranian Quarterly 10, no. 3-4 (2012): 75-96.

${ }^{7}$ Meliha B. Altunisik, and Lenore G. Martin, 'Making Sense of Turkish Foreign Policy in the Middle East under AKP', Turkish Studies 12, no. 4 (2011): 569-87; Robert W. Olson, Turkey-Iran Relations, 1979-2004, Revolution, Ideology, War, Coups, and Geopolitics (USA, Mazda Publishers, 2003); F. Stephen Larrabee, 'Turkey Rediscovers the Middle East', Foreign Affairs 86, no. 4 (2007): 103-14; Gencer Ozcan, 'Turkey's Changing Neighbourhood Policy', Turkish Yearbook of International Relations 35 (2004): 1-15.

${ }^{8}$ Bayram Sinkaya, 'Rationalization of Turkey-Iran Relations: Prospects and Limits', Insight Turkey . 14, no. 2 (2012): 13756.

${ }^{9}$ William Hale, 'Turkey and the Middle East in the "New Era"', Insight Turkey 11, no. 3 (2009): 143-159.

${ }^{10} \mathrm{John}$ Calabrese, 'Turkey and Iran, Limits of a Stable Relationship', British Journal of Middle Eastern Studies 25, no.1 (1998): 75-94.

${ }^{11}$ Suleyman Elik, Iran-Turkey Relations, 1979-2011: Conceptualizing the Dynamics of Politics, religion, and security in the middle-power states (London, Routledge, 2012).
} 
In line with these assessments, this study focuses on the change in Turkey's elitelevel discourse about Islamic fundamentalism as a threat, and Iran as an external source of this threat. It aims to contribute to the literature that analyses the domestic determinants of Turkey's Iran policy. To this aim, the study first clarifies the theoretical framework, as well as data collection and analysis. Then, it makes an analysis of Turkish elites' securitizing speeches throughout the 1990s within which Iran was referred to as a threat to Turkey's national unity and regime security. Second, it examines the desecuritization of Islamic fundamentalism as a threat to Turkey's survival during the first decade of the 2000s. It traces the change in Turkey's political structure that made desecuritization possible. The last part analyses the positive transformation in Turkish-Iranian relations by focusing on the AKP elites' foreign policy vision as an initiator of rapprochement, and change in public opinion, as well as an increase in bilateral political and economic relations as determinants of change. ${ }^{12}$ Taking Turkey's Iran policy as its case, the study contributes to the wider literature on the link between domestic politics and foreign policy by utilizing a security framework.

\section{Theory and method}

The concept and framework of securitization was developed by the group of scholars who worked at the Copenhagen Peace Research Institute to find an answer to the question 'What makes something a security issue? ${ }^{\prime 13}$ The concept of securitization came as an answer to this question, which is considered as a major constructivist challenge to the traditional security approach that is based on a realist understanding.

Securitization means 'to present an issue as an existential threat, requiring emergency measures and justifying actions outside the normal bounds of political procedure'. ${ }^{14}$ In other words, securitization refers to a process within which an actor transforms a certain issue into a matter of security. According to this approach, security is not an objective and material condition, it is rather an intersubjective act, socially constructed via language. Thus, as the Copenhagen School argues, 'something is a security problem when the elites declare it to be so $^{\prime 15} .^{15}$ If a securitizing actor presents an issue as an existential security threat, requiring the use of extraordinary means, emergency measures and other actions outside normal political conditions, it begins to be considered as a security issue/threat. ${ }^{16}$ For a securitization move to become fully successful, the target audience should accept and identify that issue as a security threat. This is why public opinion surveys are also reviewed in this study.

According to Buzan et al., securitization and desecuritization are antonymous. Thus, desecuritization refers to the shifting of issues out of emergency mode and into the

\footnotetext{
${ }^{12}$ AKP refers to Adalet ve Kalkınma Partisi, or Justice and Development Party in English.

${ }^{13}$ Ole Wæever, 'Securitization and Desecuritization', in On Security, ed. R. D. Lipschutz (New York, Columbia University Press, 1995), 54.

${ }^{14}$ Barry Buzan, Ole Wæever, and Jaap de Wilde, Security, A New Framework for Analysis (Boulder, Lynne Rienner Publishers, 1998), 24.

${ }^{15}$ Wæever, 'Securitization', 47.

${ }^{16}$ Bulent Aras, and Rabia Karakaya Polat, 'From Conflict to Cooperation, Desecuritization of Turkey's Relations with Syria and Iran', Security Dialogue 39, no. 5 (2008): 497.
} 
normal bargaining processes of the political sphere'. ${ }^{17}$ It is a process in which 'a political community downgrades or ceases to treat something as an existential threat to a valued referent object, and reduces or stops calling for exceptional measures to deal with the threat'. ${ }^{18}$ Some scholars argue that the concept of desecuritization is undertheorized and understudied comparing to securitization. ${ }^{19}$ In this sense, some scholars take lack of securitizing speeches as desecuritization, while others look for the existence of positive speeches or practices. This study applies a combination of these two approaches.

I analyse speeches of influential actors in Turkish politics (i.e. presidents, prime ministers, generals, representatives) since securitization is basically defined as 'a speech act'. In this manner, I essentially review Turkish newspapers Milliyet and Cumhuriyet between 19902002, and 2002-2011 with the keywords 'Islamic fundamentalism (irtica), threat (tehdit), Iran'. The logic behind the selection of these particular newspapers is that (1) they are two of the popular local newspapers of the time, (2) they have online archives and tools that allow the researcher make advanced search. It is also relevant to mention that the assassinations of Turkish intellectuals some of whom were members of Cumhuriyet was an important element of the crisis between Turkey and Iran during the 1990s. Milliyet, on the other hand, was considered to be a 'mainstream' newspaper in terms of its political position.

There were 75 related news reports in Cumhuriyet, and 80 in Milliyet that included all three keywords in the former time period. In the 2000s, only 26 news reports in total were published in these newspapers which contain the same keywords, and 23 of them are about how Iran and/or Islamic fundamentalism were removed from the list of national threats. ${ }^{20}$ Furthermore, the study presents political and social context within which securitization and desecuritization became possible in order not to fall into trap of reductionism by focusing only on what elites say.

\section{The 1990s: Iran as source of Islamic fundamentalism threat}

Following the Islamic Revolution of Iran, the phrase 'Turkey is not going to be Iran' became a popular expression of the fear of Islamic fundamentalism. Such anxiety about a possible spread of Islamic regime paved the way for the construction of security discourse and policies towards the Islamic Republic of Iran. In this sense, politics of fear started to play a significant role in structuring national security which reveals itself in political elite's discourses. $^{21}$ This imposed a distorted and exaggerated version of political reality by discursively creating fear within political circles as well as the society towards Iran's regime.

Kenan Evren, president of the 1980 Coup process, gave an interview to Milliyet and said that '[Iran] has a sharia regime and is trying to export it to us. We have to be very careful about this ${ }^{22 \prime}$. Despite the religious discourse accompanying the 1980 Coup of

\footnotetext{
${ }^{17}$ Buzan et al., Security, 4.

${ }^{18}$ Barry Buzan, and Ole Wæever, Regions, and Powers, the Structure of International Security (Cambridge, Cambridge University Press, 2003), 489.

${ }^{19}$ Matt McDonald, 'Securitization and the Construction of Security', European Journal of International Relations 14, no. 4 (2008): 563-587.

${ }^{20}$ I collected the data that is utilized in this article for my Master's thesis. For further details see Cagla Luleci, From Securitization to Desecuritization: Decoding Turkey's Foreign Policy Towards Iran, Dokuz Eylul University Institute for Social Sciences, (Unpublished MA Thesis, 2013).

${ }^{21}$ For further clarification on the concept of 'politics of fear' see, Jef Huysmans, Politics of Insecurity, Fear, Migration, and asylum in the EU (London, Routledge, 2006).

${ }^{22}$ Cetin Yetkin, 'Evren, İrtica Tırmanıyor', Milliyet, April 19, 1990.
} 
Turkey, and the following reflections on politics and society, Evren was concerned about the possibility of an 'Iranian version of Islamic fundamentalism' in Turkey. Below part from his memoirs of 1992 well summarizes the perspective that Evren and the majority of the political elites of the time shared about Iran's regime,

MFA (Minister of Foreign Affairs) Mesut Yilmaz came to me before the MGK meeting and said, 'The Iranian ambassador has a role in all Islamic fundamentalist movements in Turkey. ${ }^{23}$ We will deport him for this; we will recall our Tehran ambassador to Turkey; in this way, we want to demonstrate our reaction against Iran's interference in our internal affairs; we got Prime Minister [Turgut Ozal]'s consent and are asking for your approval'. I answered, 'Actually, we are even late in doing this. Iran is responsible for all the Islamic movements in Turkey. I'll approve your move. ${ }^{24}$

Post-Cold War years were marked by Turkey's secular elites' anxiety that 'secularism in Turkey was being confronted by an Islamic attack supported by external and internal groups' with the president of the constitutional court's words. ${ }^{25}$ This anxiety was further stimulated following the Sivas Massacre in 1993, which is considered to be one of the most violent acts of Islamist groups in the history of Turkish politics. On the anniversary of an Alevi folk satirical author, a festival was organized in Sivas. Aziz Nesin was one of the guests of the festival in $1993 .{ }^{26}$ Nesin was a satirical author known as an atheist critic. He had earlier translated Salman Rushdie's Satanic Verses in Turkish, which angered Islamic fundamentalist groups. Before that, Iran's Khomeini had issued a fatwa ordering that Rushdie should be killed, which was a primary reason for linking this incident to Iran. ${ }^{27}$ Due to their anger towards Nesin, radical Islamist groups started a fire in Madimak Hotel, in which the guests of the festival stayed, and killed 37 people, most of whom were Alevi intellectuals. A total of 124 out of the 190 defendants were charged with 'attempting to establish a religious state by changing the constitutional order' and indicted. ${ }^{28}$ Following the increasing anxiety within political circles as well as in public, the General Directorate of Security sent a report titled 'Iran's actions towards Turkey' to the Prime Minister and the General Staff, in which the following expressions took place:

In embassies, consulate generals, consulates and Iran Cultural Centers the attempts to export the Islamic Revolution are organized with the help of diplomatic immunity. Propaganda materials from Iran are brought in and distributed in Turkey. Meetings and memorial days are organized to inform the Turkish public about the Islamic Revolution. Our citizens that may have similar ideologies are taken to Iran for the aim of ideological indoctrination. Opponents of the Islamic regime in Turkey are followed by the Iranian secret service. They also organize intelligence gathering activities about Turkey. Internal issues such as the headscarf are applied as a means for Iran to make revolutionary propaganda. Iranian students play a considerable part in this Iranian propaganda that aims to attack Kemalist thought and secularism. ${ }^{29}$

\footnotetext{
${ }^{23}$ MGK refers to Milli Guvenlik Konseyi, or National Security Council in English.

${ }^{24}{ }^{2}$ Kenan Evren'in Anıları 5. Bolum', Milliyet, April 10, 1992.

${ }^{25}$ Oktay Akbal, 'Ya Demokrasi, Ya Irtica', Milliyet, January 12, 1993.

${ }^{26}$ In some sources, Aziz Nesin is titled also as a "Alevi folk poet."

${ }^{27}$ For further information on Rushdie's Satanic Verses see, Ali A. Mazrui, 'The Satanic Verses or a Satanic Novel? Moral Dilemmas of the Rushdie Affair', Alternatives, Global, Local, Political 15, no. 1 (1990): 97-121.

${ }^{28} \mathrm{M}$. Ali Birand, 'Son Darbe, 28 Subat Part 1', http//www.youtube.com/watch?v=GR3L4BmcZBo. (accessed August 23, 2017)

${ }^{29}$ Soner Gurel, and Tolga Sardan, 'Emniyet'ten "Iran'a Dikkat" Raporu', Milliyet, February 7, 1994.
} 
Iran was also officially accused over the assassinations of several Turkish intellectuals in the mid-1990s. The general directorate of security affairs prepared a report titled 'Terrorism and Turkey' which highlighted Iran's impact on Islamist terrorist movements in Turkey. According to the report, the group named themselves as Islamic Movement Organization, which was believed to be responsible for the assassinations of Turkish intellectuals, was 'a counterintelligence project of the Iranian intelligence service, rather than a terrorist organization'. ${ }^{30}$ The report claimed that 'After the Islamic Revolution, Iran wanted to export its regime to Turkey, and this is why many fundamentalist Islamic groups appeared, especially in the Eastern and South-Eastern cities of Turkey'. ${ }^{31}$ In 1996, the leader of Islamic Movement Organization confessed after his arrest that his organization had ties with Iran. This caused a diplomatic crisis between the two neighbours, because of which eight Iranian diplomats being expelled.

When RP came to power as the biggest coalition partner, elite concerns reached a peak. It was the first time in the Republic's history that a party with an openly religious orientation acceded to power. He made his first foreign trip to Iran and claimed that neither Iran nor Syria was sponsoring PKK terrorism and Islamic fundamentalism, despite receiving MIT reports that indicated the opposite. ${ }^{32}$ RP's Erbakan's attitude towards Iran and his discourse towards Islamic fundamentalism divided the military and bureaucratic elites' approaches towards Iran. RP was accused of undermining the secular regime, while a considerable number of people believed that the coalition government was collaborating with Iran's Ayatollah in exporting Iran's Islamic regime. ${ }^{33}$ These accusations legitimized the belief that Turkish military had to act to protect Turkey's unity and solidarity.

There was an increase in the number of news reports that were presenting Iran as a threat to Turkey's national security after the Refah-Yol coalition came into power in 1996, indicating the link between domestic fears and threat perception from foreign sources. Such tradition has been present in Turkish politics since its very foundation. The incidents that brought Turkey to the verge of the fourth military intervention of the Republic started hereby. The Sincan incident had set another peak of ideological tensions between Turkey and Iran. In 1997, 'Night for Jerusalem (Al-Quds Night)' which had been originally declared by Khomeini in 1980 as an anniversary for the Iranian Islamic Revolution, was organized in Sincan, Ankara. The then mayor of Sincan, Bekir Yıldız, was an ideological and political supporter of RP. ${ }^{34}$ Yildiz invited Mahmud bin Yasin, representative of Palestinian Liberation Organization to Turkey, and the Iranian Ambassador Muhammed Riza Bagheri to the event. In his speech in the event, with posters of Hamas and Hizbollah leaders behind him, Bagheri advised those who attended the meeting to fearlessly support sharia. ${ }^{35}$ Following that, while the meeting was still proceeding, Turkish armed forces sent 50 tanks down Sincan on the 31 st of January.

For the Turkish elites, the so-called Bagheri crisis was part of a broader campaign to form an Islamic regime in Turkey similar to Iran. It caused a great political reaction in Turkey, with both countries' ambassadors being recalled. Opposition parties and armed

\footnotetext{
${ }^{30}$ Alper Ballı, 'Terorde Iran Parmagı', Cumhuriyet, April 13, 1998.

${ }^{31}$ Ibid.

${ }^{32}$ MIT refers to Milli Istihbarat Teskilati, or National Intelligence Agency in English.

${ }^{33}$ Ozden Zeynep Oktav, 'Changing Security Perceptions in Turkish-Iranian Relations', Perceptions (Summer 2004): 105-6.

${ }^{34} \mathrm{RP}$ refers to Refah Partisi, or Welfare Party in English.

${ }^{35}$ Olson, Turkey-Iran, 35.
} 
forces defined the Sincan incident as a challenge to Turkey's secular regime and identity and an attack on the essential features of the Turkish Republic. Mayor Yıldız was sentenced 4 years and 6 months in prison, with 11 bureaucrats also being found guilty and sentenced to 10 years of imprisonment. Nurettin Sirin, a journalist in Selam newspaper, was given the longest sentence. He was sentenced to 17 years of imprisonment. Army's intervention started the 28 February process in Turkey, within which conservative gestures and events were highly seen as threat to the secular character of the regime.

Not surprisingly, February 1997 MGK meeting was the longest until then, resulting in an 18-point memorandum. ${ }^{36}$ Contrary to the usual practice, the memorandum had the characteristics of a command rather than a recommendation. The most important topics concerned Koran courses and schools, suspicious actions of religious groups, application of the dress code and limitations on Islamic capital. ${ }^{37}$ At the same meeting, generals declared that 'fundamental Islamist movements which threaten Turkey's secular democratic regime are linked to Iran', and 'Iran's attempts that would destabilize Turkey's regime should be monitored'. ${ }^{38}$

The diplomatic crisis eased with the establishment of the 55th government, which was a coalition of ANAP, DSP and DTP after the February 28 crisis. However, it was not enough for friendly relations. ${ }^{39}$ In April 1997, a retired admiral's commentary was published in which the admiral revealed information about the February 28 MGK meeting, and generals stressed the importance of Article 2 of the Turkish Constitution defining Turkey as a democratic and secular state. ${ }^{40}$ According to him, 'certain groups' wanted the country to become a 'Turkish Islamic Republic' by imitating Iranian regime. He completely disapproved this possibility, claiming that secularism and the secular identity were essential features of the Turkish Republic. Following that, once again, Turkish General Staff declared that Iran had supported Islamic fundamentalist organizations and this issue was the first priority related to domestic and foreign threats that need an immediate response and started to give private briefings titled the 'Islamic fundamentalist threat' to media members, academicians, bureaucrats, NGO members and judiciary members. The content of the briefings was as follows

The existential threat to Turkey is separatism and reactionary Islam. Destroying them is of vital importance. Iran supports organizations such as Turkish Hezbollah, Turkish Islamic Jihad and uses terror as a means for its political aims. ${ }^{41}$

MGK gave a briefing and declared that military would intervene in politics when necessary. Media members were pre-censored during this period and warnings regarding the Refah-Yol coalition government continued. ${ }^{42}$ In the text, Iran was presented as

\footnotetext{
${ }^{36}$ MGK meetings used to be held once in a month to discuss security issues and strategic goals. Prime Minister, MFA, minister of internal affairs, minister of defense, chief of staff, force commanders, secretary general of the MGK used to attend the meetings. A memorandum is prepared after each meeting, in the form of a recommendation to the government. For the policies of civil and military elites following the 28 February see also, Umit Cizre, and Menderes Cinar, 'Turkey 2002, Kemalism, Islamism and Politics in the light of the February 28 Process', The South Atlantic Quarterly 102, (2003): 309-332.

${ }^{37}$ Evren Deger, 'Hukumete Taviz Yok', Milliyet, March 31, 1997.

${ }^{38}$ Mete Belovacıklı, 'Notlar', Milliyet, March 2, 1992.

${ }^{39}$ ANAP refers to Anavatan Partisi or Motherland Party; DSP refers to Demokratik Sol Parti or Democratic Left Party, DTP refers to Demokrat Turkiye Partisi or Democrat Turkey Party.

${ }^{40}$ Tanju Erdem, 'Akıllar Başlara Alınmalıdır', Cumhuriyet, April 21, 1997.

${ }^{41}$ 'Ordu 'Írtica'yı Anlatacak', Cumhuriyet, June 5, 1997.

${ }^{42}$ Birand, 'Son Darbe.'
} 
the primary threat: 'Iran provides every kind of moral and material support to establish a Sharia regime in Turkey'. ${ }^{43}$ General Staff was also concerned about Koran courses in Istanbul and the eight-year compulsory primary education system. It formed a unit called the Western Study Group to monitor whether MGK decisions were implemented or not and to gather intelligence about Islamist groups. This unit prepared a supposedly secret report analysing Islamic fundamentalism in all its aspects warning that 'If the government does not take measures, the political part of Islamic fundamentalism will come to power on its own by the $2000 \mathrm{~s}^{\prime}{ }^{44}$

In 2000, an operation to Hizbollah was launched while the Iranian MFA was in Turkey for an official visit. Successive raids on different locations revealed tens of corpses, as well as armaments and documents. Clues were revealed related to 22 assassinations, including those of Ugur Mumcu, Bahriye Ucok and Ahmet Taner Kışlalı. Militants under surveillance revealed that they had planned and carried out the assassination under the coordination of Iranian agents, explaining that they had been trained in Iran and organized to carry out many other incidents in Turkey. ${ }^{45}$ These discoveries caused a great reaction throughout the country regarding both Islamic fundamentalism and Iran as a foreign supporter.

In 2001, FP was closed because of its links with Islamic fundamentalist movements and immediately replaced by the newly formed SP. ${ }^{46}$ However, this latest closure caused divisions within the party. The reformist wing of FP did not join SP, forming AKP instead in 2001. The leader of AKP, Erdogan, defined the party as 'democrat, conservative, reformist and modern'. After the AKP government came into power, domestic concerns related to Islamic fundamentalism began to decrease. Although some tensions with Iran remained, Islamic fundamentalism was no longer considered as an existential threat by the political elites that were in power. In connection with changing security perceptions, desecuritization of Iran in elite speeches started in the early 2000 s.

\section{The 2000s: desecuritization of Islamic fundamentalism}

The 2000s witnessed remarkable alterations in the legal and institutional structure and policy-making process in Turkey. In power since 2002, the AKP government has pursued a wide range of domestic reforms that made desecuritization of Islamic fundamentalism in Turkey possible. Europeanization process and decreasing role of the military in politics have been two significant structural developments that paved the way for change in perceptions of what constitutes a security threat. These developments made a series of political reforms possible. A liberal discourse accompanied by the reforms increased public support for policies of AKP. For example, AKP framed the issue of headscarf issue cautiously, in terms of human rights rather than merely about religious freedom, since it aims to generate broader support, and not to fall into conflict with secular circles. ${ }^{47}$

\footnotetext{
43،Ordu İrtica'yı', Cumhuriyet.

${ }^{44}$ 'Devlet İrticanın Elinde', Cumhuriyet, August 1, 1997.

${ }^{45}$ 'Dugum Cozuluyor', Cumhuriyet, May 8, 2000.

${ }^{46} \mathrm{SP}$ refers to Saadet Partisi, or Felicity Party in English.

${ }^{47}$ Filiz Başkan, 'Accommodating Political Islam in Turkish Democracy', in Democratic Consolidation in Turkey, ed. Muge Aknur (Florida, Universal Publishers, 2012), 355.
} 
Majority of the Turkish public and politicians supported the reforms that AKP initiated, which paved the way for desecuritization of Islamic fundamentalism. When the government presented an amendment for removal of headscarf ban in public institutions after elected, $75.5 \%$ of Turkish people were supportive of this initiative. Although in 2004 AKP made a proposition to remove the headscarf ban in educational institutions, the issue remained unsolved for the following years due to the disagreement between political elites. ${ }^{48}$ The government planned another reform regarding the higher education system that included proposals to increase the efficiency of Imam-Hatip Schools. That reform package was also shelved due to then-President Sezer's rejection. When the military initiated a so-called 'e-coup'49 on 27 th of April after these developments, Erdogan refused to back down, deciding instead to stand up to the military by calling early elections in which AKP took $46.47 \%$ of the total votes and got re-elected. Furthermore, by 2009 , only $5.45 \%$ of the Turkish public indicated that Turkey's first priority in foreign policy should be 'to prevent attacks on Turkey's secular structure'.50

However, in March 2008, another proposal demanded political bans of five years for 71 AKP members, including Gul. The court's verdict cut the party's public financing in half but did not close the party. By the election campaign in 2011, the party consolidated its power over the three forces that threatened its survival and agenda after 2002: the presidency, high judiciary, and military. The Higher Education Council prohibited all universities from preventing students from attending classes for students' attitudes against disciplinary regulations. This decision paved the way for allowing freedom of dress in public universities, thereby in a sense legalizing the headscarf. However, the restrictive dress code for broader public institutions remained. Confrontation reappeared in the second half of the 2000s when President Sezer claimed that Islamic fundamentalism was a threat to Turkey's unity. Increasing visibility of Islam in Turkey's public sphere intensified some secular elites' anxiety regarding Islamization of Turkey's political and social environment. When asked about Sezer's speech, Erdogan said that 'Fundamentalism exists in every religion and it is a problem for all of them. However, there is not a fundamentalist Islam threat in Turkey'. ${ }^{51}$

Security discourse is generally part of a power struggle between actors of domestic politics. Islamic fundamentalism and Iran had been claimed as threats to Turkey for many years mainly because of the struggle for power and authority between policymakers. Turkey's bureaucratic and military elites have separately believed that they are responsible for maintaining political and cultural order and modernization since the nineteenth century. ${ }^{52}$ This perception has caused mistrust between civil and military elites. The competition over responsibility to rule caused them to further securitize particular issues. Ataturk's secularist, modernist and republican principles constituted a crucial commitment for the military, forming the basis for the perception that military was responsible for protecting the secular republic sometimes against the will of civilian

\footnotetext{
${ }^{48}$ For more information on Turkey's headscarf issue see, Dilek Cindoglu and Gizem Zencirci, 'The Headscarf in Turkey in the Public and State Spheres', Middle Eastern Studies 44, no. 5, (2008): 791-806.

${ }^{49}$ On 27 April 2007, General Staff made a written statement warning the public and the government about threats against secularism on the official website of Presidency of General Staff.

50‘2009 Dış Politika Algılama Anketi (DPAA)', Uluslararası Stratejik Araştırmalar Kurumu, Ankara, August 2009.

${ }^{51}$ Yılmaz Polat, 'Erdogan Bush'la Bugun Goruşecek', Cumhuriyet, October 2, 2006.

${ }^{52}$ Aras, and Karakaya, 'From Conflict', 498.
} 
governments. ${ }^{53}$ This was also to maintain legitimacy by dramatizing threats from foreign enemies. ${ }^{54}$ On the other hand, AKP claimed to represent and fight for the needs and demands of the public, especially those who felt pushed in the periphery of social and political life for decades.

Aknur argues that desecuritization of certain issues by AKP and the Ergenekon cases caused a decrease in the military's role in politics and their prestige in the eyes of the public throughout the 2000s, especially after the 2007 elections. Throughout the 2000s, the military also lost public power at a discursive level. The military could not mobilize public opinion on many occasions and failed to gain their support for its policies. In several domestic political issues in which the government and military disagreed, particularly over the headscarf and Islamic religious education, the majority of the Turkish public took the side of the government.

This power struggle resulted in a decrease in the military's role in domestic and foreign policy by the end of the 2000s. ${ }^{55}$ Various institutional mechanisms that had previously consolidated the military's political power were removed in the 2000s through legal reforms due to the EU membership process. This process gained momentum after 2001 with the introduction of harmonization packages and constitutional reforms that aim to limit the military's political authority. In particular, constitutional amendments concerning the composition and role of MGK were decisive. Amendments in 2001 reduced the number of military members of the council while increasing the number of civilian members while the change to Article 118 of the constitution made MGK decisions merely advisory, which reduced military's power over the political decision-making process. ${ }^{56}$ EU harmonization package of 2003 banned military courts from judging civilians in peacetime and authorized the Court of Accounts to monitor any institutions benefiting from public sources, including the armed forces. ${ }^{57}$ This monitoring power was further increased with Court of Accounts Law in December 2010. The procedure for the appointment of the secretary general also changed so that 'the secretary would be appointed with the approval of the president on the proposal of the Prime Minister'. ${ }^{58}$ Removal of legal obstacles preventing a civilian becoming the Secretary-General of the MGK was decisive in this process. With the harmonization package of 2004, the article of Higher Education Board's regulations regarding the General Staff's power to choose one board member was changed limiting the military's influence over higher education. The General Staff's authority in the Radio and Television Supreme Council was also decreased, while civilian control over the military budget was tightened. ${ }^{59}$

\footnotetext{
${ }^{53}$ William Hale, and Ergun Ozbudun, Islamism Democracy and Liberalism in Turkey, The case of the AKP (London, Routledge, 2010), 80; Muge Aknur, 'The Impact of Civil-Military Relations on Democratic Consolidation in Turkey', in Democratic Consolidation in Turkey, ed. Muge Aknur (Florida, Universal Publishers): 220-21; Metin Heper, 'The Justice and Development Party Government and the Military in Turkey', Turkish Studies 6, no. 2, (2005): 215-231.

${ }^{54}$ Bulent Aras, 'Turk-İran Ilişkileri, Degişim ve Sureklilik', Avrasya Dosyası 12, no.2 (2006): 68.

${ }^{55}$ Umit Cizre, 'Secular and Islamic Politics in Turkey', in The Making of the Justice and Development Party, ed. Umit Cizre (London, Routledge, 2008): 132-171.

${ }^{56}$ Gencer Ozcan, 'The Changing Role of Turkey's Military in Foreign Policy Making', UNISCI Discussion Papers 23, (May 2010), 30.

57،Siyasi Reformlar-l', TC Avrupa Birligi Bakanlıgı, https//www.ab.gov.tr/files/rehber/04_rehber.pdf. (accessed January 10, 2018).

${ }^{58}$ Aknur, 'The Impact', 228.

59،Avrupa Birligi Uyum Yasa Paketleri', TC Başbakanlık Avrupa Birligi Genel Sekreterligi (Ankara, 2007), https//www.ab. gov.tr/files/pub/abuyp.pdf. (accessed January 10, 2018)
} 
Europeanization process and changing political culture also led to the formation and participation of NGOs in decision-making in Turkey. ${ }^{60}$ Civil society took advantage of the democratization process imposed by the EU to become increasingly involved in issues concerning politics and security. This affected foreign policy-making in Turkey in both political and economic terms. Non-state actors' involvement in political issues further demilitarized and desecuritized political domestic and foreign issues since they claimed to be presenting the public's voice. Furthermore, Turkey's foreign and security-related issues became more linked to economic concerns. ${ }^{61}$ TOBB, TUSIAD and MUSIAD for instance, are businessmen's organizations that have had a notable impact on foreign policy decisions. As Ovalı argues, not only economic and political organizations but also think tanks such as SETA and TESEV have become more influential in certain foreign policy issues. $^{62}$

In a sense, desecuritization can never be really successful because it is not possible to convince every group within society. ${ }^{63}$ Thus, in the early 2000s there were cases that indicate ongoing concerns related to Islamic fundamentalist movements in Turkey. However, the general spirit within Turkey, and of Turkish-Iranian relations was considerably more positive in the AKP period.

\section{New foreign policy vision and rapprochement with Iran}

Alienation of Iran in Turkey's foreign policy slowed down starting from the 2000 s. $^{64}$ Despite its decreasing role, MGK continued to give briefings warning against Islamic fundamentalism and Iran and bringing up AKP's roots in RP as a source of the threat. In these briefings, the issue of AKP bureaucrats that had relations with Iran and Saudi Arabia was discussed, where it was claimed that Islamic fundamentalist groups considered AKP power as signalling permission to continue their terrorist activities, suggesting that this perception needed to be prevented. ${ }^{65}$ There were also concerned circles within the civilian elite. Ecevit put their viewpoint forth while saying, 'Before the elections, I indicated that AKP might be a threat to the regime. I am still anxious'. ${ }^{66}$ The public also took external threats very seriously because they believed that Turkey's geopolitical position made it a target for 'enemies' around, which was also why the public accepted the perception that Iran's Islamic Revolution was a threat to the secular republic. ${ }^{67}$

Despite concerns of certain circles, development of friendly relations with Iran had continued smoothly until the eruption of the Arab Uprisings. AKP elites believed that political Islam can create a supra-identity acting as a common ground for solving the problems in the Muslim world, and aimed to develop intense interactions with Iran. $^{68}$

\footnotetext{
${ }^{60}$ Ozcan, 'The Changing', 25.

${ }^{61}$ Kemal Kirişci, 'Turkey's Foreign Policy in Turbulent Times', Challiot Paper, no. 92 (September 2006): $29-52$.

${ }^{62}$ A. Şevket Ovalı, 'From Europeanization to Re-Nationalization, Contextual Parameters of Change in Turkish Policy', Studia Europea 57, no. 3 (2012): 27.

${ }^{63}$ Andreas Behnke, 'No Way Out, Desecuritization, Emancipation and the Eternal Return of the Political-A reply to Aradau', Journal of International Relations and Development 9, no.1 (2006): 65.

${ }^{64}$ Nuri Yeşilyurt, 'Ortadogu'yla İlişkiler', Turk Dış Politikası Cilt III, 2001-2012, ed. Baskın Oran (Istanbul, Illetişim Yayınları, 2013): 451-52.

65'Iirtica MGK Masasında', Cumhuriyet, November 27, 2002.

${ }^{66}$ Mustafa Balbay, 'Işte Siyaset Belgesi,' Cumhuriyet, November 14, 2005.

${ }^{67}$ Aknur, 'The Impact', 207.

${ }^{68} \mathrm{H}$. Akın Unver, 'How Turkey's Islamists Fell Out of Love with Iran', Middle East Policy 19, no. 4 (2012): 103-104.
} 
Political rhetoric made it possible to deconstruct negative perceptions towards Iran and to convince the public that such a shift in Turkey's political behaviour is essential for it to increase and consolidate its power and prestige internationally. MFA Davutoglu's 'new foreign policy' initiative paved the way for desecuritizing discourse and foreign policy practices. By the end of the 2000s, not only policymakers but also the public appeared to seek friendly relations with the former enemy. Other indicators of desecuritization are the changes about Iran in National Security Policy Document of Turkey energy trade and security agreements signed with Iran, the administration's support for its neighbour's nuclear while rejecting Western demands for economic sanctions towards Iran, increasing interactions on trade and tourism. ${ }^{69}$

Change in the principles and the methods of Turkey's foreign policy in the AKP period has mostly been associated with then-MFA Davutoglu, who believes that historical and geographical composition of a state remain constant while all other elements of foreign policy should be considered as dynamic and open to change. For Davutoglu, historical and geographical elements are significant while making a rational evaluation of a country's potential and its ability to adapt to new conditions. ${ }^{70}$ Aras argues that priorly Turkey's foreign policy elites tended to establish a connection between domestic threats and the foreign policy agenda that strengthened their own privileged positions, with the effect of gradually distancing the country from its near abroad. In contrast, 'new foreign policy' is structured on the basis of 'a novel geographic imagination' that avoided the alienation of neighbour states. ${ }^{71}$ This reconstruction of Turkey's neighbours' images enabled Turkey to overcome the obstacles that were previously created by domestic policy considerations. By abandoning the 'bordering and othering' view in foreign policy, Turkey could actively engage in regional affairs. ${ }^{72}$ Thus, the Ottoman history that has previously been ignored in Turkish foreign policy is perceived as an asset by AKP elites.

Davutoglu set five main principles of Turkish foreign policy, all paved the way for active and positive relations with Iran. First, 'Balance between security and freedom' is summarized as 'Now, security is, from outside and inside, much less of an issue for Turkey'. ${ }^{73}$ Second, 'zero problems with the neighbors' aims at problem-free relations with Armenia, Greece, Cyprus, Iran, Syria, Iraq and Russia. Third, 'proactive/preventive peace diplomacy' in both neighbouring regions and globally, which calls for active engagement with all regional systems in Turkey's neighbourhood. The fourth principle, 'rhythmic diplomacy' refers to active engagement in global and international issues, together with increased presence and activism in all international and regional organizations. The fifth principle, 'multi-dimensional foreign policy' refers to multipolar characteristics of the world in the post-Cold War, and disadvantages of choosing a bloc.

\footnotetext{
${ }^{69}$ Nilufer Karacasulu, and İrem Aşkar Karakır, 'Iran-Turkey Relations in the 2000s, Pragmatic Rapprochement', Ege Academic Bakış 11, no. 1 (January 2011): 1399-1407.

${ }^{70}$ Ahmet Davutoglu, 'Principles of Turkish Foreign Policy', SETA Foundation, Washington DC, 2009, 1-18; 'The "Strategic Depth" that Turkey Needs, An Interview with Ahmet Davutoglu', The Turkish Daily News, September 15, 2001; Alexander Murinson, 'The Strategic Depth Doctrine of Turkish Foreign Policy', Middle Eastern Studies 42, no. 6 (2006): 952.

${ }^{71}$ Aras, 'Turk-Iran Illişkileri', 128.

${ }^{72}$ H. V. Houtum, 'The Geopolitics of Borders and Boundaries', Geopolitics 10, no. 4 (2005): 674.

${ }^{73}$ Davutoglu, 'Principles', 7.
} 
These goals and principles seemed to influence Turkey's Iran policy positively according to various indicators.

In the 2002 revision of MGSB, in comparison to the way it was mentioned in the 1997 MGSB, 'Iran was covertly referred to as a source of threat given its aspirations to develop nuclear power and WMDs and its continued support for the PKK'. ${ }^{74}$ Thus, although the document still mentioned Iran, the level of emphasis on Iran as a source of threat decreased in general and the main focus of the Iranian threat changed completely. While WMDs and PKK were considered as security problems (related to Iran), Islamic fundamentalism was removed from the list of threats. This changed at least the referent object from the secular regime to other spheres, such as territorial integrity and political stability. In March 2005, the 300-page draft of the next document was sent to those who were concerned, which started clashes on the content. In the part relating to Islamic fundamentalism, Iran was not mentioned as an external supporter. The most remarkable change in the document was about Iran. In the previous document, the part concerning Middle Eastern states stated that 'Iran's attempts to export Islamic regime to Turkey and its support to Islamic fundamentalist groups should be prevented'. However, this part was revised in a more positive way: 'Relations with Iran should be based on the principle of non-interference in domestic affairs and the friendly neighborhood relations principles'. $^{75}$

During the 1990s, MGSB had rewritten twice to identify Islamic fundamentalism as one of the two primary threats for internal security, along with Kurdish separatism. ${ }^{76}$ As Bilgin suggests, although the military was not the most central actor in the preparation of MGSB, it had an 'unquestioned authority over security knowledge and security speak' ${ }^{77}$ This made it possible throughout the 1990 s and in the early 2000s for military's vision to be dominant in the document. Following a change in military's position in Turkish politics, and abolishment of Islamic fundamentalism from the list of internal threats, Gul wanted MGSB to be re-written in light of the foreign policy principle of 'zero problems with neighbors' in 2010. ${ }^{78}$ His and AKP's aim was to remove the word 'Islamic fundamentalism' totally from the text and to acquit Muslim neighbours in the Middle East of being a threat for the Republic. Accordingly, in October, the threat of 'Islamic fundamentalism' was replaced with 'organizations using Islam as a political means'. ${ }^{79}$ Additionally, away from being referred to as a source of PKK threat, the document contained a call for cooperation with Iran on PKK terror. While the MGSB of 2005 included both PKK and Islamic fundamentalism as domestic threats, MGSB of 2010 excluded Islamic fundamentalism from the list of domestic threats. Instead, the document mentioned 'radical groups exploiting religion'.

Desecuritization of domestic political disputes and reshaping of socially constructed enemy images have affected Turkish elites' posture and discourse towards Iran. Throughout the 2000s, Turkish and Iranian politicians increased the frequency of bilateral visits. In the early 2000s, when Turkey aimed at strengthening its ties with

\footnotetext{
${ }^{74}$ Ozcan, 'Turkey's', 4.

${ }^{75}$ 'Iran tehdit olmaktan cıkıyor,' Cumhuriyet, June 27, 2005.

${ }^{76}$ Pinar Bilgin, 'Making Turkey's Transformation Possible: Claiming Security-speak-not Desecuritization!', Southeast European and Black Sea Studies 7, no. 4: 562.

${ }^{77}$ Bilgin, 'Making Turkey's', 563.

${ }^{78}$ Aslı Aydıntaşbaş, 'Kırmızı kitapta koklu degişim', Milliyet, August 23, 2010.

${ }^{79}$ Barkın Şık, 'Irtica İc Tehdit Olmaktan Cıktı', Cumhuriyet, October 28, 2010.
} 
its Middle Eastern Muslim neighbours, it had to make cost-benefit calculations to balance relations with the West and the East. However, the impact of structural constraints on Turkish foreign policy decreased in the following years, due to the rising self-confidence of AKP, mainly as a result of public support. In June 2006, Gul made a visit to Tehran and the next month he went to Washington, when Condoleezza Rice, praised Turkey's mediating role in the Iranian nuclear issue. The U.S. continued to support Turkey's role as mediator between Iran and the West regarding Iran's nuclear programme. As Obama put it, 'I believe that Turkey can be an important player in trying to move Iran in that direction [abiding by international rules and norms] ${ }^{80}$ According to Aras and Karakaya, Turkey's involvement in Iran's nuclear power issue has broken up the threat-security issue in two ways. First, Turkey has stopped defining Iran as an 'external other' and a source of its domestic problems. Second, the elimination of 'others' has increased Turkey's self-confidence in foreign policy. ${ }^{81}$ There has also been a shift in Turkish elites' rhetoric regarding Turkey's dependency on the U.S. in its foreign policy choices.

However, Turkey's constant rejection of sanctions on Iran stirred up criticism from the West. In June 2010, Turkey voted against UNSC resolution 1929, which proposed the fourth round of sanctions against Iran because of its nuclear programme. Erdogan administration's posture contradicted 'U.S. and Israeli policies of preventing nuclearization of a "rogue" regime that could pose an "existential" threat to Israel'. 82 Despite such criticism from the U.S., Turkish government's discourse did not change much. On his visit to the European Political Center at Brussels, Erdogan responded angrily to Western demands to reduce economic relations with Iran, claiming that

We will never cut our relations with Iran. No one can define our policy. Turkey is not a tribal state. Turkey is a powerful country that has a great history. Therefore, we decide our destiny, we take our decisions. No one can determine to whom we will talk and to whom we will not. $^{83}$

This speech did not only reflect a political decision taken by foreign policy elites but it also Turkish public's ideas on Iran's nuclear power. According to the poll conducted by Transatlantic Trends, as in past years, Turkey was the least worried about Iran acquiring a nuclear weapon. What is significant is 'only $48 \%$ of Turks were troubled by this possibility, representing a ten-point increase over the previous year'. ${ }^{84}$

The rapprochement was not result of a one-sided initiative though. AKP elites have continuously counselled the leaders and groups of Islamic countries which evoked Iranian leaders' positive attitude. Started to play an active role in regional organizations of the Middle East. A Turkish national was elected as Secretary General of the OIC and this was further considered a sign of Turkey's changing approach towards the Middle East. In the D-8 Summit in 2004, former Iranian President Khatami emphasized Turkey

\footnotetext{
80‘Obama Sees Role for Turkey in Iran Dispute', New York Times, December 7, 2009.

${ }^{81}$ Aras, and Karakaya, 'From Conflict', 508.

${ }^{82}$ Behsat Ekici, Is Turkey Realigning? A Three-Dimensional Investigation of Turkish-Iranian Security Rapprochement, Unpublished Ph.D. Thesis (USA, University of Pittsburgh, 2010), 6.

${ }^{83}$ Ekici, 'Is Turkey', 222.

${ }^{84}$ 'Transatlantic Trends 2012', 38, http,//trends.gmfus.org/files/2012/09/TT-2012-Key-Findings-Report.pdf (accessed June 11, 2016)
} 
and Iran's common regional security concerns, by saying 'Turkey's security means Iran's security'. ${ }^{85}$ Following a visit to Tehran, Erdogan also stated that

We have conducted very fruitful negotiations with the Iranians. We are giving the utmost importance to our relations with Iran in all issues. Our relations continue to develop the principles of good neighborhood and non-interference in domestic politics. We had a strategy when we took over the government. We would improve our relations with our neighbors. Turkey and Iran are two important players in regional politics. We can together do many things for regional peace. ${ }^{86}$

Change in political rhetoric has made a positive shift in Turkish public's apprehension of Iran. A public poll in 2005 showed that $71.2 \%$ of the respondents thought 'Iran is not a threat to Turkey'. When asked whether they supported an American intervention against Iran or not, $87.3 \%$ answered that they were against such attack. ${ }^{87}$ In a survey conducted in 2009 , only $1.09 \%$ of the participants referred to Iran as a source of threat for Turkey. ${ }^{88}$ Transatlantic Trends report of 2011 also shows that 'A plurality of the Turks considered Turkey's neighbors in the Middle East as more important to the country's economic interests (43\%) and security interests (42\%) than countries of the EU' because it is a Muslim country. ${ }^{89}$ According to the survey, the percentage of those who believed that NATO was essential for the country's security decreased, while support for close cooperation with the Middle Eastern countries doubled. ${ }^{90}$

AKP did not only change political discourse in a positive manner but also deepen economic ties with Iran. Iran became a significant trade partner in the AKP period. Iran became a significant trade partner for Turkey after 2002. In December 2006, during a visit to Iran, Erdogan stated that there had been $500 \%$ growth in Iran-Turkey trade in the previous four years. Rafsanjani, chairman of Iran's Expediency Council, also indicated that trade and financial relations between two countries were increasing swiftly, which was beneficial for both of them. According to official data, overall trade volume between Iran and Turkey increased $730 \%$ over the last decade. ${ }^{91}$ According to the Turkish Institute for Statistics, overall trade volume between Iran and Turkey increased $730 \%$ in the 2000 s. $^{92}$ In 2008, Iran became Turkey's seventh largest import partner and 19th largest export partner. ${ }^{93}$ Iran has begun to be considered a close trading partner by Turkey, and this new Iranian model poses no challenge to Turkish elites (Table 1).

Table 1. Turkey's foreign trade with Iran between 2002 and 2011 (millions of dollars) ${ }^{\mathrm{a}}$.

\begin{tabular}{lrrrrrrrrrr}
\hline & 2002 & 2003 & 2004 & 2005 & 2006 & 2007 & 2008 & 2009 & 2010 & 2011 \\
\hline Import & 921 & 1861 & 1962 & 3470 & 5627 & 6615 & 8200 & 3406 & 7645 & 12,462 \\
Export & 334 & 534 & 813 & 913 & 1067 & 1441 & 2030 & 2025 & 3044 & 3590 \\
\hline
\end{tabular}

a Turkish Ministry of Economy, accessed 29 December 2017, www.ekonomi.gov.tr.

\footnotetext{
${ }^{85}$ Mesut Hakkı Casin, and Gonca Oguz Gok, 'Basra Korfezinde Yukselen Nukleer Gerilimde Iran-ABD Turkiye'nin Yeni diplomatik Yol Haritaları', in Satranc Tahtasında Iran Nukleer Program, eds., Kenan Dagcı, and Atilla Sandıklı (Ankara, Tasam Yayınları, 2007), 56.

${ }^{86}$ Ekici, 'Is Turkey', 256.

87.'Amerika Dost Degil', Yeni Şafak, February 5, 2005.

${ }^{88}$ DPAA.

${ }^{89}$ 'Transatlantic Trends 2011', 4, http//www.gmfus.org/publications_/TT/TT2011_final_web.pdf. (accessed June 11, 2016)

${ }^{90}$ Ibid., 37.

${ }^{91}$ 'Foreign Trade Statistics', Turkish Institute for Statistics (TUIK), http//www.tuik.gov.tr. (accessed February 23, 2016)

${ }^{92}{ }^{\prime}$ Foreign Trade Statistics', Turkish Institute for Statistics, http//www.tuik.gov.tr. (accessed February 23, 2013)

${ }^{93}$ Foreign Trade Statistics.
} 
The share of natural gas in Turkish-Iranian trade relations has been particularly significant for political ties. Before 2002, Turkey purchased less than $4 \%$ of its natural gas requirements from Iran. In contrast, new contracts throughout the AKP period have increased the overall volume of natural gas trade between Iran and Turkey steadily. ${ }^{94}$ Iran became the second largest natural gas suppliers of Turkey, following Russia. ${ }^{95}$ During the 2000s, Erdogan and Ahmadinejad continually stated their willingness to develop broader bilateral cooperation on energy, security, transportation, and industry. Erdogan stated that

Both countries' investors share the same economic concerns and future prospects. We are really happy with the rise of bilateral trade to over $\$ 10$ billion. To increase the volume more, we as the politicians will eliminate the barriers, and the investors will do the rest. When we attain a trading volume of $\$ 30$ billion, Turkey and Iran will be in a very advanced situation'.96

In a meeting in Ankara, Turkish side described Iran and Turkey as two great states of the Middle East. The representative added, 'Turkey and Iran's common history and civilization is the most important reason for having close relations', and 'These two neighboring countries should enjoy the most expanded border cooperation and opening the doors of new border customs posts is especially important for the expansion of cooperation'. ${ }^{97}$ There has also been an increase in the number of Iranian tourists to Turkey in the 2000s, as an indicator of developing cultural ties. This increase is important since it both maintains and demonstrates developing cultural relations. The number of Iranian tourists quintupled from 2002 to 2011 with the highest number among all Muslim countries. ${ }^{98}$

These developments seem to suggest that the security-driven atmosphere in TurkishIranian relations in the 1990s turned into a rapprochement in the 2000s. While Turkey's fear of an Islamic regime became the main source of tension in Turkey's Iran policy, desecuritization of Islamic fundamentalism made it possible to develop a positive political environment between Turkey and Iran.

\section{Conclusion}

Change in Turkey's foreign policy towards Iran from the 1990s to the 2000s was remarkable. While Iran's regime was considered as a threat to national security in the 1990s, two states became close partners in politics and economy in the following decade. This study finds out how Turkey's domestic political considerations influence this change in its foreign policy preferences and practices towards Iran. Analysing Turkey's domestic political environment in these two decades, the study offers that Turkish elites securitized the Islamist regime of Iran in the pre-AKP period, which had implications for the tensions in bilateral relations between two states. When the new political elites of AKP government started to define national security in a different way, it became possible to build friendly relations with Iran. Thus, the study claims that the

\footnotetext{
${ }^{94}$ TUIK.

${ }^{95}$ 'Energy Market Regulatory Authority 2009', Petrol Piyasasi Sektor Raporu, http,//www.epdk.org.tr/TR/Dokumanlar/ Petrol/YayinlarRaporlar/Yillik. (accessed January 2, 2018)

96،'Başbakan Erdogan'dan Iran'da ekonomik mesajlar', Stargazete, October 27, 2009.

97'Iran-Turkey Agree to Boost Cultural, Educational Ties', Fars News Agency, February 17, 2010.

${ }^{98}$ Yeşilyurt, 'Ortadogu'yla', 460.
} 
desecuritization of Islamic fundamentalism in domestic politics paved the way for a rapprochement between two states. Starting from 2002, cooperation in politics and security, as well as bilateral economic and trade relations, bilateral visits, and connection between two states' societies had increased. This rapprochement was accompanied by an elite-level discourse that presents Iran as a friend and ally in the region.

The main question of this study is 'How did the desecuritization of Islamic fundamentalism in Turkey's domestic politics influence its foreign policy towards Iran?'. Answering such question, it finds out that securitization of Islamic fundamentalism in domestic politics influenced Turkey's Iran policy in a negative way, while change in elite perceptions regarding Islamic fundamentalism threat in Turkey paved the way for rapprochement between two states. In this sense, this research makes two contributions, one theoretical, and one empirical. Theoretically, it contributes to the literature that analyses the link between domestic politics and foreign policy by utilizing a securitization framework that is generally used to understand only domestic politics. The study suggests that securitization framework can be a useful tool to analyse the domestic political roots of foreign policy behaviours of states. Empirically, the study contributes to the literature on Turkish politics and foreign policy by focusing on elite discourse and state practices in two successive decades. This way, it observes the change in foreign policy discourse and practices. Moreover, merging domestic and foreign political concerns is a very common practice in world politics. In this sense, the study reveals insights on understanding current foreign policy issues, including Turkey's political discourse and foreign policy behaviour towards the European Union and the Middle East. By making such linkage via a securitization framework, this study can open up new areas of analysis for the study of both securitization and foreign policy.

By its main problematic and research question, this study focuses on the process in which securitization and desecuritization of Islamic fundamentalism became possible in Turkish politics, and how these changes influenced its Iran policy. It specifically aimed to find out 'how come' Turkey and Iran became close friends in the 2000s despite their conflictual relations in the 1990s. In this sense, it does not specifically focus on the reasons or causes behind the change in Turkey's foreign policy, but rather looks at the process in which Islamic fundamentalism and Iran had been constructed as threats, and how this threat perception was deconstructed by the new elites. However, one may consider this study as a starting point to understand the context and to build up another research that analyses possible reasons behind such shift in Turkey's foreign policy. Referring to the research that this article conducts, change in elite identity, power shift between military and civilian elites, and Davutoğlu's new foreign policy might be tested as possible causes that led to a positive change in Turkey's Iran policy in the 2000s.

\section{Disclosure statement}

No potential conflict of interest was reported by the author.

\section{ORCID}

Cagla Luleci-Sula (D) http://orcid.org/0000-0002-0534-8271 